\title{
3 EU external climate policy
}

\author{
Gill Allwood
}

\section{Introduction}

Climate change has arrived centre-stage on the EU's policy agenda. The new President of the Commission, Ursula von der Leyen, announced in 2019 that Europe would be the first climate-neutral continent by 2050 and introduced the European Green Deal and the first EU climate laws as part of the project to achieve this goal. Externally, the EU plays a major role in international climate negotiations, partly to meet its global leadership aspirations, and partly to ensure that European manufacturing is not undercut by producers with lower environmental standards. Climate change also features prominently in EU foreign policy, where it is framed as part of a series of nexuses, connecting it with migration, security and conflict. The need to address climate change rests against a backdrop of crisis - economic, environmental, health and political - building a sense of urgency and strategic prioritisation. One of the consequences of this is the sidelining of gender equality, despite the EU's repeated assertions of its commitment to mainstreaming the goal of gender equality throughout all its internal and external activities.

This chapter draws on feminist institutionalism and the literature on policy integration, including gender mainstreaming, to show how and why gender is excluded from EU external climate policy. It asks, firstly, where, in external climate policy, do we find references to gender and what, if anything, do they contribute to achieving gender-just climate policy. Secondly, it asks how feminist institutionalism and policy integration studies can help us understand why gender equality is not mainstreamed in EU external policy and what institutional obstacles prevent its integration. I argue that gender has been excluded from EU external climate policy by a combination of institutional power struggles; a discourse of crisis and security, which pushes gender into the background; and a proliferation of nexuses and mainstreaming imperatives in which the treaty obligation to mainstream gender is pushed to one side.

\section{EU climate policy}

EU climate policy has three main components: mitigation, adaptation and climate diplomacy. Mitigation refers to strategies for reducing climate change,

DOI: $10.4324 / 9781003052821-3$ 
largely through the reduction of greenhouse gas emissions. Adaptation refers to strategies for adapting to the effects of climate change, such as increased flooding, droughts and unpredictable weather patterns. Climate diplomacy refers to the EU's role in international climate negotiations and agreements, an area in which it has sought to assert leadership. However, financial, economic, and political crises from 2008 slowed internal climate policy, and internal opposition to strong climate action has grown, particularly from central and eastern European member states, including Poland (Dupont and Oberthür, 2015, p. 229). While initially, the EU's ambitions exceeded its own internal practice, since the mid2000s it has tried to 'lead by example'. The EU, along with its member states, is a signatory to the United Nations Framework Convention on Climate Change (UNFCCC) and plays a key role in trying to reach agreements on global targets (Biedenkopf and Dupont, 2013). The EU was an influential player in the 2015 Paris Agreement, the first universal, legally binding climate agreement and continues to try to push global targets upwards (Oberthür and Groen, 2018).

Key policy frameworks are the Climate and Energy Package for the period 2020-2030 (COM [2014] 15 final), which sets out targets for greenhouse gas emissions reductions, renewable energy and energy efficiency; and the Environmental Action Programme, which provides an overarching framework for all environmental and climate policy. The European Green Deal (2019) sets out a strategy for achieving net-zero greenhouse gas emissions by 2050 while sustaining economic growth. The first 'climate law' (COM [2020] 80 final) was proposed in early 2020, aiming to enshrine in legislation the objective of climate neutrality by 2050 .

Since 2013, internal EU climate policy has also included an adaptation strategy, in recognition that climate change is having an impact within the EU, as well as, more obviously, elsewhere. While climate change mitigation was more readily framed as an issue to be dealt with at the EU level, adaptation to the effects of climate change appeared, until recently, to require local responses or to be of concern only in countries hit most severely by the impact of climate change, which are concentrated in the Global South. The floods and heatwaves of the early 2000s raised awareness of the impact of climate change within the EU and of its cross-border nature (Rayner and Jordan, 2010). As a consequence, the EU's adaptation strategy was adopted in 2013 (COM(2018) 738 final). Member states are encouraged to produce national adaptation strategies, setting out, for example, how they will climate-proof their transport, energy and agriculture sectors, and protect their populations from flooding, droughts and heatwaves. As part of EU external relations, however, adaptation has a longer history. The visible impact of climate change in developing countries, and the use of development aid for adaptation purposes, means that climate change has long been prominent in EU development policy. A Commission Communication in 2003 (COM [2003] 85 final) declared climate change a development, as well as an environmental, problem. This has implications for the study of gender and EU climate policy, as will be demonstrated later. The well-established nature of gender and development within the European Commission and the European 
Parliament (especially its FEMM Committee on Women's Rights and Gender Equality and the Committee on Development) means that adaptation has been the core concern of gender and climate change analyses and policy proposals emanating from these institutions.

The EU's internal and external climate policies are dealt with by different decision-making institutions and processes. The European Commission is responsible for drafting EU legislative proposals. The newly appointed President, Ursula von der Leyen, has declared climate change one of her top priorities, and the European Green Deal (2019) was introduced as one of the new Commission's first actions. Internal EU climate policy is proposed by the Commission DirectorateGeneral for Climate Action, DG CLIMA, which was created in 2010. However, climate change cannot be addressed by discrete policy measures. Energy, environment, agriculture, transport and trade all play a crucial role. Successfully meeting climate targets requires other policy sectors to integrate climate change into their work, as will be discussed later in this chapter.

Externally, climate change appears in foreign, security, external migration and international development policy. Since the Paris Agreement (2015), external climate policy has included supporting partner countries with the formulation and implementation of their Nationally Determined Contributions (European Commission, 2019, p. 62). The EU's Global Climate Change Alliance Plus initiative $(\mathrm{GCCA}+)$ has fostered policy dialogue with, and support for climate action in partner countries, mainly Least Developed Countries (LDCs) and Small Island Developing States (SIDS) (European Commission, 2019, p. 64). Before the Lisbon Treaty (2009), climate change, like other EU policy issues, was expected to align with the principle of Policy Coherence for Development. Policy Coherence for Development is a treaty obligation and is intended to prevent EU policies in areas other than international development undermining development objectives. This applies to all EU activities, including climate action. Impact assessments are supposed to be conducted to ensure that proposed actions will not have adverse effects on developing countries. However, the relative weakness of development policy institutions within the EU; the hierarchy of political priorities; and the poor implementation of the impact assessment obligation mean that Policy Coherence for Development has been more of a rhetorical commitment than an accomplishment. The Lisbon Treaty (2009) brought about a shift in emphasis, with development objectives being set alongside new strategic priorities, such as security and migration, and then gradually losing place to them. Development policy is increasingly required to serve the interests of a securityfocused foreign policy. According to the Global Strategy (High Representative of the Union for Foreign Affairs and Security Policy 2016), which is the overarching statement of EU foreign policy, 'Development policy needs to become more flexible and aligned with our strategic priorities'. EU foreign and security policy frames climate change as a security threat and a root cause of migration (High Representative of the Union for Foreign Affairs and Security Policy 2016, p. 27). The Council Conclusions on Climate Diplomacy of 26 February 2018 state that: 'without decisive action [climate change and environmental degradation] will 
become an even greater source of global risk, including forced displacement and migration'. Development policy is now expected to mainstream climate change adaptation to render partner countries more resilient when coping with climate change consequences in order to address the root causes of the migration crisis. The European Consensus on Development (2017) calls for climate change integration across all sectors of development cooperation. It commits to addressing the root causes of migration, including climate change. This is a reversal of the expectation prior to the Lisbon Treaty that climate action would be coherent with development policy objectives.

The European Commission's framing of the EU's global role stresses the importance of access to

partner countries' markets, infrastructure and critical raw materials. This starts with enhancing the EU's energy and climate diplomacy, and with further mainstreaming climate change objectives and considerations in political dialogues, including in the area of migration, security and development cooperation.

(COM [2018]773 final)

Climate mainstreaming is seen as a way to achieve the EU's trade, security and migration priorities, and is, therefore, a core priority for external action.

\section{Where does gender fit into EU external climate policy?}

This section of the chapter gives an overview of EU gender equality policy, showing where it intersects with climate policy. Focusing on external climate policy, it then asks where we can find references to gender and what, if anything, they contribute to achieving gender-just climate policy.

The EU is committed to mainstreaming gender throughout all of its internal and external activities. Article 8 of the TFEU states: 'in all its activities, the Union shall aim to eliminate inequalities, and to promote equality, between men and women'. EU institutions still tend to frame gender equality as 'equality between men and women', ignoring the heterogeneity of these two categories, the power relations within, as well as between, them, and the intersection of other structural inequalities with gender. There are institutional pockets in which a more nuanced gender analysis emerges. These will be discussed where they relate to external climate policy. The EU's approach to gender equality is contained in its Gender Equality Strategy, the most recent version of which was launched in March 2020. The strategy makes some move away from a focus on equality between women and men, aiming to achieve

a Europe where women and men, girls and boys, in all their diversity, are equal ... The Commission will enhance gender mainstreaming by systematically including a gender perspective in all stages of policy design in all EU 
policy areas, internal and external. The Strategy will be implemented using intersectionality as a cross-cutting principle.

Although there is no detail about how this will be done, the recognition of intersectionality is an important step away from equating gender equality solely with a men-women binary. An intersectional analytical lens has been used by feminist scholars to make important contributions to our understanding of the impact of climate change and responses to it (Nagel, 2012; Tschakert and Machado, 2012; Kaijser and Kronsell, 2014; MacGregor, 2014; Sultana, 2014). Intersectionality can help us understand individual and group-based differences in relation to climate change. Rather than designating women as vulnerable victims of climate change, an intersectional approach demonstrates that social structures based on characteristics such as gender, socio-economic status, ethnicity, nationality, health, sexual orientation, age and place influence the responsibility, vulnerability and decision-making power of individuals and groups. For example, Kronsell's (2013) study of Sweden shows that there are gendered differences in energy consumption and transportation. She argues, however, that it is important to recognise that gender is not the only relevant factor; sometimes class matters more than gender and there are considerable differences within the Global North and Global South. An intersectional analysis asks which social categories are included in, and excluded from, the cases in question, what assumptions are made about social categories, and what type of knowledge is privileged (Kaijser and Kronsell, 2014). Buckingham and Le Masson (2017, pp. 2-3) argue that,

If gender, and gender equality, is to be a meaningful policy objective, it must be recognised that it comprises relations between women and men, and between and among different groups of women and men, not to mention between different conceptualisations of masculinity and femininity, which can each be practised by either, and both, women and men ... Understanding gender inequality also requires a simultaneous understanding of social and economic divisions based on class, ethnicity, age, disability, religion, sexuality, parenthood, among others, and how these divisions intersect to compound particular disadvantages and inequalities between and within social groups.

Internally, the EU's concern with gender equality has focused primarily on equal pay for equal work, a principle enshrined in the treaties since the Treaty of Rome (1957). The EU has been committed to gender mainstreaming since 1996, meaning that gender equality should be integrated into all areas and at all stages of policy-making. However, key areas of activity remain untouched, including energy, trade and transport. The European Parliament's FEMM Committee has highlighted many of these gaps in a series of reports and resolutions, as has the European Institute for Gender Equality (EIGE). For example, EIGE (2016), finds that the European Commission has only just begun to recognise the links between gender and transport, and according to the European Parliament (2018), 
'current EU trade policy and its "Trade for All” strategy ... lack a gender equality perspective'.

Gender equality and women's empowerment are declared core objectives of EU external action (Gender Equality Strategy 2020-2025). Since 2015, the second Gender Action Plan (GAPII), has required all actors in EU external action to implement and report on gender mainstreaming, specific actions and political dialogue in relation to gender equality. GAPII also introduced a cross-cutting priority: Institutional Cultural Shift. This was based on the recognition that gender equality will only be achieved once there is a significant change in institutional culture. It will be discussed in the next section of this chapter. The original Gender Action Plan (2010) was created within the Directorate-General (DG) for Development and aimed to translate gender and development commitments into effective policy outcomes. This illustrates the importance of EU development policy institutions in raising awareness of gender equality, gender mainstreaming and gender analysis. The strong influence within DG Development of Gender and Development experts and advocates has resulted in development cooperation being the most gender-aware area of EU policy. In the wake of the Lisbon Treaty, the creation of the European External Action Service, and the restructuring of DG DEVCO, the second Gender Action Plan, GAPII (20152019), applied to all areas of EU external action, not just development policy, and to all actors, including EU headquarters in Brussels, EU delegations in partner countries and member states. This shift from development to external action has diluted the influence of gender and development activists and advocates on the framing of gender equality issues, and gender equality remains less well integrated into areas of external action outside international development.

Development policy documents continue to enshrine a long-standing commitment to gender equality. For example, the European Consensus on Development (2017, para 15) states that:

gender equality is at the core of the EU's values and is enshrined in its legal and political framework. It is vital for achieving the SDGs and cuts across the whole 2030 Agenda. The EU and its Member States will promote women's and girls' rights, gender equality, the empowerment of women and girls and their protection as a priority across all areas of action.

In line with the UN's 2030 Agenda and with growing awareness of diversity and intersectionality, the European Consensus on Development (2017, para 16) moves beyond a focus on gender alone:

the EU and its Member States will continue to play a key role in ensuring that no-one is left behind, wherever people live and regardless of ethnicity, gender, age, disability, religion or beliefs, sexual orientation and gender identity, migration status or other factors. This approach includes addressing the multiple discriminations faced by vulnerable people and marginalised groups. 


\section{Gill Allwood}

Statements of commitment to gender mainstreaming are pervasive in EU foreign and security policy, including external climate policy. The Global Strategy (High Representative of the Union for Foreign Affairs and Security Policy 2016, 11 and 51), states that: 'we must systematically mainstream human rights and gender issues across policy sectors and institutions'. The Council Conclusions on Climate Diplomacy of 26 February 2018, state that: 'gender equality, women's empowerment and women's full and equal participation and leadership are vital to achieving sustainable development, including climate change adaptation'. The Council Conclusions on Climate Diplomacy of 18 February 2019 state that: 'the EU will continue to uphold, promote and protect human rights, gender equality and women's empowerment in the context of climate action'. The European Council Strategic Agenda 2019-2024, sets out as one of its four main priorities a climate-neutral, green, fair and social Europe, stating that 'Europe needs inclusiveness and sustainability, embracing the changes brought about by the green transition, technological evolution and globalisation, while making sure no-one is left behind'. In this section, it adds: 'we need to do more to ensure equality between women and men, as well as rights and opportunities for all. This is both a societal imperative and an economic asset'.

These statements can be read as all-embracing or as add-ons to unchanged gender-blind policy. They are now systemic in EU external policy and can provide leverage for gender equality advocates, both inside and outside EU institutions, but they can also suggest that the problem has been resolved, removing incentives to address it.

In contrast, the European Green Deal (2019) is completely gender blind. It makes no reference to gender/women, although it does say that the transition to a climate-neutral economy must be 'just and inclusive' and must 'put people first' (p. 2). The European Green Deal mostly concerns internal policy, but a section on 'the EU as a Global Leader' stresses the importance of increasing climate resilience in partner countries to avoid 'conflict, food insecurity, population displacement and forced migration'. The EU's efforts to 'lead by example' in climate action are important, but the gender blindness of climate policy means that any norms it exports will also be gender blind.

One of the reasons why gender is absent from the European Green Deal is that (gender) equality and climate action are presented as two of the new Commission's top priorities, but they are kept separate from one another. Elements of genderawareness in relation to climate change exist in fragments of EU policy, but they lack coherence. The Gender Equality Strategy has a short section on climate change which points out some of the ways in which climate change is gendered and argues that, 'Addressing the gender dimension can therefore have a key role in leveraging the full potential of these policies'. GAPII refers to climate issues only twice. The first reference states that the Commission's services and European External Action Service will contribute to 'women's increased participation in decision-making processes on climate and environmental issues' and Objective 20 in Annex 1 is: 'equal rights enjoyed by women to participate in and influence decision-making processes on climate and environmental issues'. 
This is the objective least often reported upon. There are also reports on gender and climate change by EIGE and the European Parliament, some of which are limited to counting the numbers of women in climate decision-making, and some of which contain sophisticated gender analyses of climate issues and responses. The EIGE (2019) report, for example, reiterates the EU's obligations to integrate gender equality into its climate change policies, in line with the UNFCCC Lima Work Programme on Gender and the 2017 Gender Action Plan, as well as with the EU's own gender mainstreaming commitments. However, EIGE argues that these have not been translated into concrete actions, and EU climate policy has remained largely gender blind.

To summarise, climate change is mentioned briefly in gender equality documents, such as GAPII and the Gender Equality Strategy, but the major climate framework document of 2019, the European Green Deal, is gender blind. The Social Development Goals (SDGs) offer the potential to bring gender equality and climate change together, but this has not yet been realised, including within EU policy-making.

\section{A feminist institutionalist analysis of gender and EU external climate policy}

The previous section has shown that gender equality is not mainstreamed in EU external climate policy. Can feminist institutionalism help us to understand why this is the case? Feminist institutionalism tells us that institutions matter, that they are ridden with gendered power relations, and that they are resistant to change. Feminist institutionalism (Mackay et al., 2009; Krook and Mackay, 2011; Chappell and Waylen, 2013; Waylen, 2013) can help explain the gap between formal commitments to gender mainstreaming and gender equality in all policy areas and at all stages of policy-making and, on the other hand, persistently gender-blind policy in particular areas, in this case, climate change. It enables us to examine the institutional constraints, opportunities and resistances that affect gender mainstreaming within climate change policy-making. Feminist institutionalism emphasises the importance of informal practices, norms and values, exposing the ways in which they can constrain or distort formal rules (Chappell and Waylen, 2013; Waylen, 2013). A focus on the informal rules of the game provides clues that can contribute to explaining the gap between the rhetoric and reality of gender mainstreaming in specific areas of EU policy. Focusing on the relation between formal rules and informal practices can help us understand why gender mainstreaming - which is formally compulsory in all policy areas and all stages of policy-making - is ignored, overlooked, pushed down the agenda or out to the margins, while the main business of climate change policy-making continues unperturbed. Drawing on sociological institutionalism, feminist institutionalism suggests that actors are constrained by cultural conventions, norms and cognitive frames of reference which privilege a certain way of thinking about a policy problem and ensure that other perspectives remain submerged from view (Lowndes and Roberts, 2013, p. 30). Feminist discursive institutionalism also enables us to 


\section{Gill Allwood}

focus on the construction and contestation of meaning in the interaction between gender mainstreaming and climate change policies (Schmidt, 2012). Gender mainstreaming is interpreted and re-interpreted in day-to-day institutional interactions. Individual and collective actors engage in struggles to impose their understandings of gender mainstreaming, and this is affected by the broader context of institutional power imbalances that push issues such as gender equality to the centre or the margins of particular policy debates. It can reveal ways in which gender mainstreaming is imbued with new meanings in day-to-day policy-making practices. It can highlight the ways in which issues are constructed as certain types of problem requiring certain types of solution. This can act as a constraint on those pushing other meanings. The special issue of Political Studies Review on gender and external action shows that in times of crisis, gender equality is pushed off the agenda (Muehlenhoff et al., 2020). Studies on the gendered impact of COVID-19 have revealed the same effect (John et al., 2020). Crisis discourse wrongly proclaims that 'we are all in this together', whereas Cynthia Enloe (2020) insists that

we are not all in this together. We're on the same rough seas, but we're in very different boats. And some of those boats are very leaky. And some of those boats were never given oars. And some of those boats have highpowered motors on them. We are not all in the same boat.

The EU's institutions have very different institutional cultures. The European Parliament, for example, has traditionally been greener and more gender equality-friendly than the Council, but can be squeezed out of decision-making, particularly in areas where member states seek to retain control. The Council has retained exceptional control of climate policy-making, meaning that the member states have more influence and the European Parliament has less influence than is set out in the treaties (Dupont, 2019). Climate and gender equality laggards, often from central and eastern Europe, can water down policy in both of these areas. EU decision-making is famously sectoral, although some crosssectoral structures exist, for example, the European Parliament's gender mainstreaming group and the promised Task Force for Equality in the Commission. Power relations between external climate institutions affect their relative ability to frame climate change. For example, the European Parliament Development Committee and the European Commission's Directorate-General for development are relatively weak. In contrast, security and migration institutions and frames are dominating the external climate policy agenda (Youngs, 2014). The Lisbon Treaty enhanced external action, but reduced the profile of development within it. There is also a gap between policy formulation in Brussels and implementation by the EUDs in the partner countries. As Debusscher and Manners (2020) point out, it is not just about what happens in the institutions in Brussels. External climate policy is also made and implemented in the delegations in the partner countries and in partnership with the partner countries. Studies have shown that gender mainstreaming is not consistently present in these institutions and processes (Allwood, 2018). 
Institutional resistance to gender-sensitive change was recognised in GAPII which applies to all external action and contains an important cross-cutting priority: Institutional Cultural Shift. This means 'shifting the Commission services and the European External Action Service's institutional culture to more effectively deliver on EU commitments'. Institutional Cultural Shift was based on the idea that change will only be brought about once a systemic shift has taken place. This aligns with Rao and Kelleher's (2005) work on gender and organisations, which argues that effective gender mainstreaming needs transformational institutional change. It is a response to the recognition that organisations matter and that they are 'sticky'. Path dependency might explain why climate change continues to be framed as a scientific, elitist, technical and masculinised issue. As Cornwall and Rivas (2015, p. 400) argue, 'Ultimately, a paradigm transformation is needed to reclaim the gender agenda and address the underlying structures of constraint that give these inequalities the systemic character and the persistence over time'.

Institutional Cultural Shift and changing mindsets are essential for gender transformation, but will not be effective without political will. Gender composition at management level in the European External Action Service is worse than in the European Parliament, European Commission and Council. Chappell and Guerrina (2020, p. 8) find that,

A common normative stance within the European External Action Service has not yet fully evolved, indicating that where a gender perspective does occur, it is unlikely to have dispersed across the European External Action Service. Hence, there may well be 'pockets' of gender actorness, but not full gender mainstreaming. From an institutional perspective, this relates not only to how many women are working within the European External Action Service but also whether officials are looking at EU foreign policy through a gender lens.

Efforts to integrate gender equality in the institutions continue. The European External Action Service Gender and Equal Opportunities Strategy 2018-2023,

aims to achieve gender equality in the European External Action Service in the broadest sense, whereby women and men enjoy equal rights, equal obligations and equal opportunities across the Service ... through accelerated progress towards gender balance and accelerated Institutional Cultural Shift in the European External Action Service.

This is justified in terms of productivity and effectiveness:

measures will be put in place for the sustainable transformation of institutional reflexes and individual mindsets. Transformational measures will aim to counteract stereotypes, unintended bias and prejudices while at the same 
time fostering inclusivity, diversity and collaboration through training, mentoring, coaching, networking and innovative learning and through providing equal development opportunities for women and men.

However, the European Parliament draft report on Gender Equality in the EU's Foreign and Security Policy 2019/2167 (INI), of 27 March 2020, calls for more precision and specific targets on gender and diversity in this strategy. It also calls for member states to create a formal Council working group on gender equality, argues that the European External Action Service Principal Advisor on gender equality requires more staff and resources, and calls on the Vice President/High Representative to ensure that heads of European Union Delegations (EUDs) abroad ensure that gender equality is mainstreamed throughout all of the delegation's work and that there is a full-time gender focal point in each delegation.

An additional obstacle to mainstreaming gender throughout all EU external climate policy is that the latter is itself constructed as a cross-cutting issue. Gender mainstreaming is implemented more easily in discrete policy sectors and is more difficult to apply to other cross-cutting issues. There is a long-standing and widespread understanding that some objectives cannot be reached by treating them as standalone goals, but that they need to be woven into all areas of decision-making and at all stages. This is referred to as mainstreaming (as in gender mainstreaming), policy integration (as in environmental policy integration), or policy coherence (as in policy coherence for development). Collectively, they can be referred to as horizontal policy coordination. Gender mainstreaming, environmental policy integration and policy coherence for development are all treaty-based obligations. As policy-makers increasingly refer to cross-cutting issues and to policy nexuses, we need a way to understand and improve how they intersect.

We can draw on the literature on horizontal policy coordination and policy nexuses to try to understand how policy issues interconnect and what happens when they do. This literature considers how cross-cutting issues are integrated into policy sectors. It shows where this works and where it fails, and suggests explanations for these outcomes (De Roeck et al., 2018). It suggests that successful policy coherence requires a strong shared vision which acts as a strategic goal and maintains focus on the objective, and not on the procedural tools and instruments. The substantial literature on gender mainstreaming shows that, despite repeated rhetorical commitments by EU actors, it is still absent from key policy areas and is often treated as procedural, rather than substantive (Meier and Celis, 2011; Allwood, 2013; Guerrina and Wright, 2016). Kok and de Corninck's (2007, pp. 587-599) study of climate change mainstreaming shows that organisational structures were not designed for cooperation, coordination and joint decision-making on different levels. There are power imbalances between different Commission DGs; between different configurations of the Council of Ministers; and between the Council, the European Parliament and the Commission. The European Parliament, and in particular its various 
committees on the environment, development and gender equality, have been increasingly active in advocating the mainstreaming of these issues throughout all European Parliament decision-making, but the European Parliament can be excluded from forms of decision-making dominated by intergovernmentalism, and this applies to most of the Union's climate change policy. Power imbalances and inter-institutional rivalries mean that issues such as environmental protection can struggle to impinge on policies shored up by powerful economic interests such as trade and agriculture. Institutional resistance, often based on powerful economic interests, is identified as the main obstacle by Gupta and van der Grijp (2010), in their study of climate change mainstreaming. Climate change mainstreaming threatens the status quo and unsettles the vested interests of industry and the energy lobby. Resistance is therefore strong. Any policy competition or struggle for scarce resources will expose these imbalances, and rhetorical commitment to mainstreaming may lack underlying substance, particularly in times of economic crisis.

EU external policy increasingly uses the term 'nexus' to describe the intersection between two or more policy areas (Lavenex and Kunz, 2009; Carbone, 2013; Furness and Gänzle, 2017; De Roeck et al., 2018). Climate change is situated in a series of nexuses, including climate-security and climate-migration. The Council Conclusions on Climate Diplomacy of 26 February 2018 'resolve ... to further mainstream the nexus between climate change and security in political dialogue, conflict prevention, development and humanitarian action and disaster risk strategies'. While this is an important recognition that policy issues are intersecting and cannot be addressed in isolation from each other, it raises substantial questions about how gender can be mainstreamed throughout other cross-cutting issues. Allwood (2020a) found that gender equality is absent from the migration-security-climate nexuses which are driving development policy priorities. This makes mainstreaming even more challenging. Not only are climate change, migration and other cross-cutting issues to be mainstreamed in development cooperation and policy dialogue, but the nexus between them must also be mainstreamed. This raises questions about the practicalities of addressing complex webs of intersecting issues, especially when some of them are accorded priority status. It also creates a context in which the mainstreaming of gender becomes even more difficult.

\section{Conclusion}

This feminist institutionalist analysis of EU external climate policy shows that the framing of climate change as a policy problem affects which institutions address it and which solutions are proposed. When climate change was framed as a development issue, decisions were made by development institutions in the context of policy coherence for development. The relatively strong influence of gender and development in DG DEV meant that there was some chance of external climate policy being tinged with gender awareness. Following the Lisbon Treaty, the creation of the European External Action Service, and the restructuring of DG 
DEVCO, foreign and security policy gained prominence, and development policy became subservient to its priorities. Given that gender was relatively prominent in development policy, this contributed to gender slipping down the agenda. Crisis discourse accentuated this trend (Muehlenhoff et al., 2020).

External relations gained prominence on the EU's political agenda with the adoption of the Lisbon Treaty. The creation of the role of High Representative and the European External Action Service marked a new era in foreign and security policy. These new institutional arrangements had consequences for both climate policy and gender equality. The new external agenda prioritised migration and security, and climate change was constructed as an external issue in relation to these priorities. The EU makes much of its foundational myth of gender equality (MacRae, 2010), and of the fact that gender equality is a fundamental value of the Union. Commitments to gender equality and to gender mainstreaming as a means of achieving it, abound in EU policy documents, both internal and external. Internal gender equality policy is closely linked to equality between women and men in the workplace. Present in the treaties since the foundation of the Common Market in 1957, equal pay for equal work (and later, work of equal value) has been at the heart of the EU's gender equality narrative, even as the principle has extended to other areas of EU policy and has slowly begun to include other forms of inequality, discrimination and exclusion. Gender equality in external relations was, for many years, most visible in relation to development cooperation, which was influenced by gender and development theory and practice. Gender awareness was higher than in other parts of EU external action and the Gender Action Plan of 2010, demonstrated a desire to implement commitments to gender equality on the ground. This constituted an institutional context in which climate change as an issue affecting developing countries and the EU's relations with them could potentially begin to be addressed in a gender-just fashion. However, the reframing of climate change as a migration and security issue has acted as an obstacle to this.

The construction of climate change as a problem which can be solved with market, technological and security solutions has, until recently, excluded a people-centred approach, which could favour a gender-sensitive policy. There are signs that this is beginning to change very slowly. EU climate policy is edging away from an exclusive focus on technological solutions towards a recognition that climate change affects people, and that people are part of the solution. However, integrating diversity and intersectionality into the analysis of climate change and proposed responses to it is still a marginal concern (Allwood, 2020b). Efforts to address gender inequality and efforts to address climate change continue to exist in parallel, rather than being fully integrated into each other. Gender equality is not integrated into all aspects of decision-making and at all stages. Instead, it is tagged on or addressed in separate documents and debates, in what Acosta et al. $(2019$, p. 15) refer to as a 'stale reproduction of set pieces of text [pointing to] significant levels of inertia in thinking and practice around gender mainstreaming issues'. This is a result of institutional stickiness, which makes it difficult to bring about a much-needed Institutional Cultural Shift. 
In addition to contributing to our understanding of why gender has not been integrated into climate decision-making, this chapter also opens up the broader question of how we can integrate gender throughout all (intersecting) policy in a way that is transformative and sustainable (i.e. not just inserting the word gender into policy documents, as Sherilyn MacGregor fears (2014, p. 624). If, as the SDGs suggest, gender equality is a prerequisite for achieving sustainable development, peace and security, and climate change mitigation and adaptation, then it must be integrated into all of these policy areas, including the intersections between them.

\section{References}

Acosta M., van Bommel S. and van Wessel M. (2019) 'Discursive Translations of Gender Mainstreaming Norms: The Case of Agricultural and Climate Change Policies in Uganda', Women's Studies International Forum, 74, pp. 9-19.

Allwood G. (2013) 'Gender Mainstreaming and Policy Coherence for Development: Unintended Gender Consequences and EU Policy', Women's Studies International Forum, 39, pp. 42-52.

Allwood G. (2018) Transforming Lives? CONCORD Report EU Gender Action Plan II: From Implementation to Impact. Brussels: CONCORD.

Allwood G. (2020a) 'Gender Equality in European Union Development Policy in Times of Crisis', Political Studies Review, 18(3), pp. 329-345.

Allwood G. (2020b) 'Mainstreaming Gender and Climate Change to Achieve a Just Transition to a Climate-Neutral Europe', Journal of Common Market Studies. https://doi .org/10.1111/jcms.13082

Biedenkopf K. and Dupont C. (2013) 'A Toolbox Approach to the EU's External Climate Governance', in Boening A., Kremer J.-F., and van Loon A. (eds) Global Power Europe Volume 1. Berlin: Springer-Verlag, pp.181-199.

Buckingham S. and Le Masson V. (2017) 'Introduction', in Buckingham S. and Le Masson V. (eds) Understanding Climate Change Through Gender Relations. London and New York: Routledge, pp. 1-12.

Carbone M. (2013) 'International Development and the European Union's External Policies: Changing Contexts, Problematic Nexuses, Contested Partnerships', Cambridge Review of International Affairs, 26(3), pp. 483-496.

Chappell L. and Guerrina R. (2020) 'Understanding the Gender Regime in the European External Action Service', Cooperation and Conflict, 55(2), pp. 261-280.

Chappell L. and Waylen G. (2013) 'Gender and the Hidden Life of Institutions', Public Administration 91(3), pp. 599-615.

Cornwall A. and Rivas A. (2015) 'From "Gender Equality" and "Women's Empowerment" to Global Justice: Reclaiming a Transformative Agenda for Gender and Development', Third World Quarterly, 36(2), pp. 396-415.

De Roeck F., Orbie J. and Delputte S. (2018) 'Mainstreaming Climate Change Adaptation into the European Union's Development Assistance', Environmental Science $E$ Policy, 81, pp. 36-45.

Debusscher P. and Manners I. (2020) 'Understanding the European Union as a Global Gender Actor: The Holistic Intersectional and Inclusive Study of Gender+ in External Actions', Political Studies Review, 18(3), pp. 410-425.

Dupont C. (2019) 'The EU's Collective Securitisation of Climate Change', West European Politics, 42(2), pp. 369-390. 
Dupont C. and Oberthür S. (2015) 'The European Union', in Bäckstrand K. and Lövbrand E. (eds) Research Handbook on Climate Governance. Cheltenham: Edward Elgar, pp. 224-236.

European Commission (2019) Supporting the Sustainable Development Goals across the World. Joint Synthesis Report of the European Union and its Member States 2019.

Enloe, C. (2020) 'Why the Use of "War" Narratives are Dangerous in Times of COVID19', Interview with Quaker Council for European Affairs. Brussels: QCEA, https://ww w.youtube.com/watch?v=Gaif6mTwFw8, accessed 18 February 2021.

European Institute for Gender Equality (EIGE) (2016) Gender in Transport. Vilnius: EIGE. European Parliament (2018) Report on Gender Equality in EU Trade Agreements, (2017/2015(INI), https://oeil.secure.europarl.europa.eu/oeil/popups/ficheprocedure.do ?lang=en\& reference $=2017 / 2015$ (INI), accessed 18 February 2021.

Furness M. and Gänzle S. (2017) 'The Security-Development Nexus in EU Foreign Relations after Lisbon: Policy Coherence at Last?', Development Policy Review, 35(4), pp. 475-92.

Guerrina R. and Wright K. (2016) 'Gendering Normative Power Europe: Lessons of the Women, Peace and Security Agenda', International Affairs, 92(2), pp. 293-312.

Gupta J. and van der Grijp N. (2010) Mainstreaming Climate Change in Development Cooperation: Theory, Practice and Implications for the European Union, Cambridge: Cambridge University Press.

High Representative of the Union for Foreign Affairs and Security Policy (2016) Shared Vision, Common Action: A Stronger Europe. A Global Strategy for the European Union's Foreign and Security Policy, http://europa.eu/globalstrategy/en, accessed 18 February 2021.

John N., Casey S.E. and Carino G., (2020) 'Lessons Never Learned: Crisis and GenderBased Violence', Developing World Bioethics, 20(2), pp. 65-68.

Kaijser A. and Kronsell A. (2014) 'Climate Change through the Lens of Intersectionality', Environmental Politics, 23(3), pp. 417-433.

Kok M. and de Coninck H. (2007) 'Widening the Scope of Policies to Address Climate Change: Directions for Mainstreaming', Environmental Science and Policy, 10, pp. 587-599.

Kronsell A. (2013) 'Gender and Transition in Climate Governance', Environmental Innovation and Societal Transitions, 7, pp. 1-15.

Krook M.L. and Mackay F. (2011) 'Introduction', in Krook Mona L and Mackay F (eds). Gender, Politics and Institutions: Towards a Feminist Institutionalism. Basingstoke: Palgrave, pp. 1-20.

Lavenex S. and Kunz R. (2009) 'The Migration-Development Nexus in EU External Rleations', in Carbone M. (ed). European Integration. Policy Coherence and EU Development Policy. Abingdon and New York: Routledge, pp. 439-457.

Lowndes V. and Roberts M. (2013) Why Institutions Matter. The New Institutionalism in Political Science. Basingstoke: Palgrave Macmillan.

MacGregor S. (2014). 'Only Resist: Feminist Ecological Citizenship and the Post-Politics of Climate Change', Hypatia, 29(3), pp. 617-633.

Mackay F., Monro S. and Waylen G. (2009) 'The Feminist Potential of Sociological Institutionalism', Politics and Gender, 5(2), pp. 253-262.

MacRae H. (2010) 'The EU as a Gender Equality Polity: Myths and Realities', Journal of Common Market Studies, 48(1), pp. 153-172.

Meier P and Celis K (2011) 'Sowing the Seeds of its Own Failure: Implementing the Concept of Gender Mainstreaming', Social Politics, 18(4), pp. 469-489. 
Muehlenhoff H.L., van der Vleuten A. and Welfens N. (2020) 'Slipping Off or Turning the Tide? Gender Equality in European Union's External Relations in Times of Crisis', Political Studies Review, 18(3), pp. 322-328.

Nagel J. (2012) 'Intersecting Identities and Global Climate Change', Identities, 19(4), pp. $467-476$.

Oberthür S. and Groen L. (2018) 'Explaining Goal Achievement in International Negotiations: The EU and the Paris Agreement on Climate Change', Journal of European Public Policy, 25(5), pp. 708-727.

Rao A. and Kelleher D. (2005) 'Is there Life after Gender Mainstreaming?, Gender and Development, 13(2), pp. 57-69.

Rayner T. and Jordan A. (2010) 'Adapting to a Changing Climate: An Emerging EU Policy?', in Jordan A, Huitema D, Van Asselt H. (eds). Climate Change Policy in the European Union. Cambridge: Cambridge University Press, pp. 145-166.

Schmidt V. (2012) 'Foreword', in Lombardo E and Forest M (eds). The Europeanization of Gender Equality Policies. A Discursive-Sociological Approach. Basingstoke: Palgrave Macmillan, pp. xiii-xvi.

Sultana F. (2014) 'Gendering Climate Change: Geographical Insights', The Professional Geographer, 66(3), pp. 372-381.

Tschakert P. and Machado M. (2012) 'Gender Justice and Rights in Climate Change Adaptation: Opportunities and Pitfalls', Ethics and Social Welfare, 6(3), pp. 275-289.

Waylen G. (2013) 'Informal Institutions, Institutional Change, and Gender Equality', Political Research Quarterly, 61(1), pp. 212-223.

Youngs R. (2014) Climate Change and EU Security Policy: An Unmet Challenge. Brussels: Carnegie Europe. 